\title{
ANALISIS PENENTUAN TARIF RAWAT INAP BERDASARKAN VARIABLE COSTING PADA RUMAH SAKIT GMIM SILOAM SONDER
}

\author{
Cristian M Pandey ${ }^{1}$, Inggriani Elim² ${ }^{2}$, Sherly Pinatik ${ }^{3}$ \\ "1,2,3 Jurusan Akuntansi, Fakultas Ekonomi dan Bisnis, Universitas Samratulangi, Jl. Kampus Bahu, Manado, \\ 95115. Indonesia" \\ E-mail: Christianmesias25@gmail.com
}

\begin{abstract}
The success of a hospital is very much determined by the accuracy of the leadership's ability to manage costs. The variable costing method is an alternative method for calculating the cost of production, which separates cost information according to behavior in relation to changes in the volume of activities. The purpose of this study was to analyze the determination of hospitalization rates based on variable costing at GMIM Siloam Sonder Hospital.The analytical method used in this study is a qualitative descriptive method. Where this method discusses a problem in detail by collecting data and processing it and concluding the results of the analysis. The results of the study according to calculations based on variable costing are the cost of a room per day per person hospitalized VIP rooms of Rp. 385,665 first class rooms of Rp. 246,391 class II rooms of Rp. 192.152 and class III rooms of Rp. 126,243 while the rates set by the hospital differ from those examined by the author through the coting variable method. So it needs to be evaluated because it is less relevant to the current conditions.
\end{abstract}

Keywords: variable costing and hospitalization rates

\section{PENDAHULUAN}

Pelayanan kesehatan merupakan kebutuhan yang mendasar bagi masyarakat. Dimaana dengan fasilitas publik yang bergerak dibidang kesehatan merupakan bagian utama yang sangat di butuhkan oleh masyarakat. Tujuannya untuk memenuhi kebutuhan masyarakat dalam menjamin pelayanan kesehatan bagi mmasyarakat. Masyarakat sangat bergantung pada fasilitas public seperti Rumah Sakit, karena sewaktu-waktu terjadi masalah kesehumahatan di masyarakat, maka hal pertama yang dibutuhkan adalah pertolongan pertama dari pihak kesehatan seperti Rumah Sakit. Hal ini menunjukan adanya hubungann yang sangat mempengaruhi antara kedua belah pihak dari masyarakat dan rumah sakit. Hal ini di tunjukan dengan adanya kebutuhan dari masyarakat kepada rumah sakit, dan sebaliknya rumah sakit bertujuan untuk menjamin kebutuhan kesehatan di masyarakat.

Rumah sakit menyediakan berbagai fasilitas-fasilitas yang berhubungan dengan kesehatan, diantaranya adalah fasilitas umum seperti ruang perawatan ,ruang peninapan dan fasilitas yang spesifik berdasarkan bagian-bagian kesehatan yang ada di rumah sakit tersebut. Bukan hanya itu Rumah Sakit juga menyediakan pelayanan jasa lewat dokter dan perawat. Sehingga harus diperhatikan juga kemampuan untuk menangani pasien secara baik. Rumah sakit Siloam Sonder pada sekarang ini telah memiliki banyak prestasi dan kemajuan yang sangat signifikan, hal ini di nilai dari perkembangan pembangunan secara fisik dan peningkatan fasilitas pelayanannanya dalam meningkatkan mutu pelayanan kesehatan yang ada di Rumah Sakit Siloam Sonder. Sehigga Rumah Sakit Siloam Sonder sudah banyak dikenal oleh masyarakat diluar Sonder.

Berdasarkan data keuangan di rumah sakit Siloam Sonder, menunjukan adanya peningkatan pendapatan dengan meningkatnya pelayanan yang ada di rumah sakit ini, sehingga dengan pendapatan yang meningkat telah mampu membayar tenaga medis dari 
seluruh pegawai dan karyawan yang ada di rumah sakit Siloam Sonder. Hal ini juga telah memberi jaminan kesejahteraan bagi pegawai dan karyawan yang bekerja di rumah sakit Siloam Sonder, sehingga dari pihak yayasan rumah sakit telh dengan baik memperhatikan dan menjamin para kegawai dan karyawan yang bekerja di runah sakit ini. Salah satu penentu keberhasilan suatu Rumah Sakit adalah kemampuan mengelola biaya dalam Rumah Sakit, dan juga yang harus diperhatikan seorang pemimpin dalam suatu perusahaan menentukan harga pokok yang ada supaya dapat dijangkau oleh konsumen dan juga relevan dengan keadaan yang ada untuk meningkatkan keuntungan pada perusahaan tersebut. Oleh sebab itu dalam penelitian ini peneliti akan menggunakan variable costing dalam menentukan harga tarif inap Rumah Sakit pada Rumah Sakit Siloam Sonder. Metode variable costing adalah untuk menghitung harga pokok produksi dengan hanya menghitung biaya produksi variable saja, biaya-biaya yang diperhitungkan sebagai harga pokok produksi dalam metode ini merupakan biaya produksi variable yang dibagi dari biaya overhead pabrik variable, biaya bahan baku langsung dan biaya tenaga kerja langsung.

\section{TINJAUAN PUSTAKA}

Pengertian Akuntansi. Akuntansi secara umum ialah salah satu cabang ilmu yang mempelajari tentang seni dan teknik untuk mengukur, menjabarkan serta memberikan sebuah kepastian yang berguna untuk menjadi landasan utama bagi para pengguna akuntansi seperti manajer, akuntan, auditor untuk menghasilkan sebuah kepastian. Menurut Wensen, Manossoh, dan Pinatik" (2016) "Akuntansi memiliki peranan yang sangat besar sebagai alat pembantu dalam pengambilan keputusankeputusan ekonomi. Bagi dunia usaha, akuntansi sangat dibutuhkan untuk membantu melancarkan tugas manajemen, khususnya dalam melaksanakan fungsi perencanaan dan pengawasan. Oleh sebab itu akuntansi banyak dipelajari oleh para usahawan. Menurut Skousen (2010:3), mendefinisikan akuntansi merupakan suatu aktivitas jasa yang adalah untuk menyediakan informasi-informasi kuantitatif, terutama yang mempunyai sifat dalam pengambilan keputusan ekonomis dalam mememberikan keputusan dan pilihan-pilihan yang logis diantara berbagai tindakan alternatif.

Pengertian Akuntansi Manajemen. Pengertian akuntansi manajemen menurut Simamora (2012:12), menyatakan bahwa akuntansi manajemen adalah proses pengidentifikasian, pengukuran, penghimpun, penganalisian, penyusunan, penafsiran dan penyampaian informasi yang membantu para manajemen dalam mencapai tujuan-tujuan organisasi. Menurut Mursyidi (2008:9), akuntansi manajemen menitik beratkan pada penyusunan laporan keuangan perbagian dalam suatu organisasi, sehingga akuntansi manajemen disebut pula akuntansi intern. Menurut Mulyadi (2014:15), informasi akuntansi manajemen dapat dihubungkan dengan tiga hal:

1. Objek informasi, seperti produk departemen, atau aktivitas, maka akan dihasilkan konsep informasi akuntansi penuh.

2. Alternatif yang dipilih, maka akan dihasailkan konsep informasi akuntansi diferensial, yang sangat diperlukan oleh manajemen dalam pengambilan keputusan pemilihan alternatif.

3. Wewenang manajer, dihasilkan konsep informasi akuntansi pertanggungjawaban, yang terutama bermanfaat untuk mempengaruhi perilaku manusia dalam organisasi.

Pengertian Akuntansi Biaya. Menurut Mulyadi (2010:8), biaya adalah pengorbanan sumber ekonomi yang di ukur dalam satuan uang, yang telah terjadi atau yang kemungkinan akan terjadi untuk tujuan tertentu. Ada empat unsur pokok dalam definisi biaya tersebut yaitu Biaya merupakan pengorbanan sumber ekonomi, diukur dalam satuan uang, yang telah terjadi atau yang secara potensial akan terjadi, pengorbanan tersebut untuk tujuan tertentu. Menurut (Antameng, Lambey, dan Gamaliel). Akuntansi manajemen adalah penerapan 
konsep dan metode yang tepat dalam mengelolah data ekonomi masa lalu dan membuat proyeksi masa depan suatu usaha untuk membantu manajemen dalam penyusunan rencana (tujuan) perusahaan dan pengambilan keputusan untuk mencapai tujuan tersebut (Antameng, Lambey, dan Gamaliel).

Variable Costing. Menurut Darise, Saerang dan Wangkar (2016)" "Metode variabel costing adalah metode untuk menentukan harga pokok produk dengan hanya memperhitungkan biaya produksi variabel saja, biaya-biaya yang diperhitungkan sebagai harga pokok produksi dalam metode variabel costing adalah biaya produksi variable yang terdiri dari biaya bahan baku langsung, biaya tenaga kerja langsung, dan biaya overhead pabrik variable. Metode Variable Costing Ditinjau dari Sudut Penentuan Harga Pokok Produksi Full costing sering disebut absorption/convetional costing adalah metode penentuan harga pokok produksi yang membebankan seluruh biaya produk baik yang berprilaku tetap maupun variabel kepada produk.Dalam laporan rugi laba variable costing tersebut biaya tetap disajikan satu kelompok tersendiri yang harus ditutup dari laba kontribusi yang diperoleh perusahaan, sebelum timbul laba bersih. Dengan demikian semua biaya tetap dalam satu kelompok tersendiri dalam laporan rugi laba. Menurut Prawironegoro (2009: 233) Variabel Costing adalah pengorbanan sumber daya untuk menghasilkan barang atau jasa dimana hanya diperhitungkan biaya variabel saja, yang terdiri dari biaya bahan baku, biaya tenaga kerja langsung dan biaya overhead pabrik variabel.

Manfaat Variable Costing. Menurut Hilton (2008: 263) laporan keuangan yang disusun berdasarkan metode variable costing bermanfaat bagi manajemen untuk:

1. Perencanaan laba jangka pendek. Dalam jangka pendek biaya tetap tidak berubah dengan adanya perubahan volume kegiatan sehingga hanya biaya variabel yang perlu dipertimbangkan oleh manajemen.

2. Pengendalian biaya. Biaya tetap dikelompokkan kedalam dua golongan yaitu discretionary fixed cost dan commited fixed cost. Discretionary fixed cost merupakan biaya yang berprilaku tetap karena kebijakan manajemen dalam jangka pendek. Biaya ini dapat dikendalikan oleh manajemen. Sedangkan commited fixed cost merupakan biaya yang timbul dari pemilikan pabrik, equipmen dan organisasi pokok. Dalam jangka pendek biaya tersebut tidak dapat dikendalikan oleh manajemen.

3. Pengambilan keputusan. Pihak manajemen dengan menggunakan metode variable costing dapat menentukan pengambilan keputusan misalnya dalam hal pesanan khusus. Menurut Kabib, Nurrokhmini, dan Hastutik (2017) kata kunci yang menjadi pembeda antara metode full costing dan variable costing adalah pengakuan biaya overhead pabrik tetap (BOP-T). Jadi, saat BOP-T diperhitungkan maka full costing dan apabila BOP-T tidak diperhitungkan maka hal tersebut variable costing. Namun demikian dalam pembuatan laporan harga pokok produksi sebagai bagian daripada harga pokok penjualan dan laporan laba-rugi semua biaya harus dilaporkan untuk memenuhi konsep full disclosure dalam akuntansi keuangan.

\section{METODE PENELITIAN}

\section{Jenis dan Sumber Data}

Jenis Data. Data kualitatif di dapat dalam penelitian ini yaitu berupa wawancara langusng kepada sekretatris Rumah Sakit dan juga berupa dokumentasi berupa sejarah Rumah Sakit struktur organisasi, dan informasi lainnya yang diperlukan dan relevan dengan penulisan ini. Data kuantitatif adalah data-data mengenai seluruh biaya-biaya yang dikeluarkan seperti biaya tenaga kerja langsung, dalam hal ini pemeriksaan dokter, biaya listrik dan air, biaya obat-obatan dan biaya makan selama tiga tahun terakhir (2016-2018). Data kuantitatif disni juga dapat diperoleh dari laporan keuangan Rumah Sakit. Data primer adalah data langsung 
dikumpulkan oleh peneliti dari sumber pertamanya. Data yang dipakai dalam penelitian ini adalah data primer, yaitu memperoleh data melalui wawancara dan pelaporan biaya dengan Sekretaris Rumah Sakit Siloam GMIM Sonder secara Langsung.

Metode Analisis. Menurut Suryabarata (2013) Penelitian kualitatif adalah penelitian yang bermaksud memahami fonomena tentang apa yang dialami oleh subjek penelitian secara holistic dan dengan cara deskriptif dalam bentuk bahasa,pada suatu konteks khusus yang alamia dan dengan memanfatkan berbagai metode alamiah. Penelitian kualitatif "Metode analisi yang digunakan dalam penelitian ini adalah metode deskriptif kulitatif yaitu menggambarkan perhitungan harga pokok kamar rawat inap yang ada pada Rumah sakit siloam GMIM Sonder.

\section{HASIL ANALISIS DAN PEMBAHASAN}

\subsection{Hasil Analisis}

Untuk menentukan biaya rata-rata rawat inap tiap kelas pada Rumah Sakit GMIM Siloam Sonder dengan metode variable costing, maka penulis terlebih dahulu menerapkan klasifikasi biaya dengan mengidentifikasi biaya tersebut apakah termasuk biaya tetap atau biaya variabel menurut perilakunya dalam hubungannya dengan penambahan volume kegiatan. Biaya rata-rata per pasien rumah sakit merupakan biaya yang terjadi untuk melaksanakan kegiatan pelayanan kesehatan terhadap pasien rawat inap. Biaya ini terdiri dari biaya tenaga kerja langsung dan biaya overhead. Penelitian ini menggunakan variable costing (biaya variabel) dimana biaya variabel adalah biaya yang jumlah totalnya berubah secara sebanding dengan perubahan volume kegiatan, semakin besar volume kegiatan maka semakin besar pula jumlah total biaya variabel. Maka biaya yang diperhitungkan kedalam biaya rata-rata adalah semua biaya yang bersifat variabel. Metode variable costing jug adalah sebuah metode alternatif untuk menghitung harga pokok produksi, yang memisahkan informasi biaya menurut perilaku dalam hubungannya dengan perubahan volume kegiatan. Metode variabel costing ini mampu menghasilkan informasi yang sangat bermanfaat bagi manajemen dalam perencanaan laba jangka serta pengendalian biaya tetap yang lebih baik dan pengambilan keputusan jangka pendek. Rumah Sakit GMIM Siloam Sonder menentapkan tarif yang akan di bebankan kepada pelanggan/pasien yang sudah di sesuaikan dgn pelayanan yang baik dan maksimal. Dan berikut adalah daftar tarif pada Rumah Sakit GMIM Siloam Sonderyang dapat di lihat melalui tabel berikut.

Tabel 1. Daftar Tarif Rawat Inap Rumah Sakit GMIM Siloam Sonder

\begin{tabular}{clrr}
\hline No. & \multicolumn{1}{c}{ Uraian } & $\mathbf{2 0 1 7}$ & \multicolumn{1}{c}{$\mathbf{2 0 1 8}$} \\
\hline 1 & Konsultasi Dokter Umum & Rp. 40.000 & Rp. 40.000 \\
2 & Konsultasi Dokter spesialis & Rp. 150.000 & Rp. 150.000 \\
3 & Kunjungan Dokter Kelas 1 & Rp. 60.000 & Rp. 60.000 \\
4 & Kunjungan Dokter kelas 2 & Rp. 50.000 & Rp. 50.000 \\
5 & Kunjungan dikter kelas 3 & Rp. 45.000 & Rp. 45,000 \\
6 & Kamar Kelas I & Rp. 225.000 & Rp. 225.000 \\
7 & Kamar Kelas II & Rp. 140.000 & Rp. 140.000 \\
8 & Kamar Kelas III & Rp. 100.000 & Rp. 100.000 \\
9 & Cek Gizi & Rp. 30.000 & Rp. 30.000 \\
10 & Pemasangan Infus & Rp. 100.000 & Rp. 100.000 \\
11 & Tindakan Pasang Catheter & Rp. 70.000 & Rp. 70.000 \\
12 & Pemasang Hekting & Rp. 100.000 & Rp. 100.000 \\
\hline
\end{tabular}

Sumber : Rumah Sakit GMIM Siloam Sonder 


\subsection{Pembahasan}

Perhitungan Harga Berdasarkan Variable Costing. Jadi harga biaya rata-rata berdasarkan variable costing terdiri dari unsur biaya dan akan ditampilkan dalam tabel yang akan disusun dan di bagi mejadi 4 (empat) bagaian sesuai kelas kamar di rumah sakit sebagai berikut:

Tabel 2. Laporan Biaya Rata-Rata Rawat Inap Kamar VIP dalam 1 periode tahun 2017

\begin{tabular}{lr}
\hline Biya tenaga kerja langsung : Dokter \& Perawat sebagai Jasa Pelayanan & Rp. 275.200 .000 \\
Biaya overhead Rumah sakit & \\
1.Biaya makan pasien & Rp. 67.000 .000 \\
2.Biaya cucian & Rp. 5.500 .000 \\
3.Biaya listrik dan air & Rp. 20.750 .000 \\
4.Biaya rekam medik & Rp. 6.000 .000 \\
5.Biaya kebersihan & Rp. 7.500 .000 \\
6.Biaya tiket & Rp. 800.000 \\
7.Biaya bahan medis habis pakai & Rp. 126.724 .000 \\
\hline Jumlah & Rp. 510.624 .000 \\
\hline
\end{tabular}

Sumber: Rumah Sakit GMIM Siloam Sonder

Setelah melakukan perhitungan total biaya rawat inap yang dikeluarkan dari kamar VIP, maka kita akan bisa menghitung biaya rata-rata yang akan diperlukan untuk operasional per orang sebagai berikut:

Harga kamar per orang = Harga pokok rawat inap selama setahun di bagi dengan Jumlah hari rawat inap selama setahun sehingga akan mendapatkan hasil harga kamar inap per hari $=\mathrm{Rp}$. 510.624.000 : $1324=$ Rp. 385.665,67. Dengan tarif kamar inap kamar VIP yang sebelumnya ditetapkan oleh rumah sakit sebesar Rp. 375.000 dan jika di bandingkan dengan hasil yang didapat dengan mengunakan metode variable costing sebesar Rp. 385.667 maka dapat dilihat yang ditetapkan di tetapkan oleh pihak rumah sakit terlalu rendah."

Tabel 3. Laporan Biaya Rata-Rata Rawat Inap Kamar I dalam periode 1 periode tahun 2017

\begin{tabular}{lr}
\hline Biaya tenaga kerja langsung : Dokter \& Perawat & Rp. 265.000 .000 \\
Biaya overhead Rumah sakit & \\
1.Biaya makan dan minum & Rp. 59.160 .000 \\
2.Biaya cucian & Rp. 3.300 .000 \\
3.Biaya listrik dan air & Rp. 16.400 .000 \\
4.Biaya rekam medik & Rp. 6.000 .000 \\
5.Biaya kebersihan dan umum & Rp. 8.500 .000 \\
6.Biaya tiket & Rp. 800.000 \\
7.Biaya bahan medis & Rp. 126.724 .000 \\
\hline Jumlah & Rp. 485.884 .000 \\
\hline
\end{tabular}

Sumber: Rumah Sakit GMIM Siloam Sonder

Jika sudah melakukan perhitngan total biaya rawat inap pada kamar kelas I, maka kita akan bisa menghitung biaya rata-rata yang diperlukan untuk biaya per orang sebagai berikut:

Harga pokok kamar per hari per orang: $=$ Rp. 485.884.000 = Harga pokok rawat inap selama setahun di bagi dengan Jumlah hari rawat inap selama setahun sehingga akan didapatkan harga tarif rawat inap kamar per hari = Rp. 485.884.000 : $1972=$ Rp. 246.391,48. Dengan mengunakan variable costing maka di dapatkan hasil perolehan dengan harga pokok kamar kelas I sebesar Rp 256.391, jika dibandingkan dengan tarif yang sudah ditetapkan rumah 
sakit sebelumnya sebesar Rp 225.000 maka berdasarkan hasil analisis yang di dapat tarif yang ditetapkanrumah sakit terlalu rendah terlalu rendah jika di bandingkan dengan tarif berdasarkan penentuan variable costing.

Tabel 4. Laporan Biaya Rata-RataRawat Inap Kamar II periode 1 Januari- 31 Desember 2017

\begin{tabular}{lr}
\hline Biaya tenaga kerja langsung : Dokter \& Perawat sebagai jasa pelayanan & Rp. 154.000 .000 \\
Biaya overhead rumah sakit & \\
1. Biaya makan dan minum & Rp. 52.160 .000 \\
2. Biaya cucian & Rp. 2.000 .000 \\
3. Biaya listrik dan air & Rp. 9.625 .000 \\
4. Biaya rekam medik & Rp. 6.500 .000 \\
5. Biaya umum dan kebersihan & Rp. 8.000 .000 \\
6. Biaya tiket & Rp. 700.000 \\
7. Biaya bahan medis habis pakai & Rp. 126.724 .000 \\
Jumlah & Rp. 395.709 .000 \\
\hline
\end{tabular}

Sumber: Rumah Sakit GMIM Siloam Sonder

Jadi setalah mengadakan penghitungan dengan mengetahui total biaya rawat inap dari kamar kelas II, maka kita akan bisa menghitung biaya rata-rata yang diperlukan untuk operasional per orang sebagai berikut:

Harga pokok kamar keseluruhan perhari dalam satu orang = Harga pokok rawat inap selama setahun di bagi dengan Jumlah hari rawat inap selama setahun $=$ Rp. 359.709.000 : $1872=$ Rp. 192.152,24. Dengan mengunakan metode variable costing dengan menghitung biaya ratarata yang ditetapkan maka di dapatkan hasil sebesar Rp 192.152 jika di bandingkan dengan tarif yang sudah di tetapkan rumah sakit sebelumnya sebesar Rp 150.000. Maka tarif yang ditetapkan rumah sakit menggunakan perhiutangan konvensional adalah terlalu rendah jika dibandingkan dengan hasil analisis berdasarkan variable costing. Oleh sebab itu rumah sakit harus mengkajii kembali tarif sudah ditetapkan supaya relevan dengan keadaan sekarang.

\section{Tabel 5. Laporan Biaya Rata-Rata Rawat Inap Kamar III periode 1 Januari- 31 Desember 2017}

\begin{tabular}{lr}
\hline Biaya tenaga kerja langsung : Dokter \& Perawat jasa pelayanan & Rp. 135.862 .500 \\
Biaya overhead & \\
1. biaya makan pasien & Rp. 52.160 .000 \\
2. biaya cucian & Rp. 2.000 .000 \\
3. biaya listrik dan air & Rp. 9.625 .000 \\
4. biaya rekam medic & Rp. 6.000 .000 \\
5. biaya kebersihan & Rp. 8.500 .000 \\
6. biaya tiket & Rp. 700.000 \\
7. biaya bahan medis habis pakai & Rp. 108.586 .500 \\
Jumlah & Rp. 323.424 .000 \\
\hline
\end{tabular}

Sumber: Rumah Sakit GMIM Siloam Sonder

Setelah mengkalkulasi hasil dari biaya rawat inap pada kamar kelas III, maka setelah itu menghitung biaya rata-rata yang diperlukan untuk operasional per orang sebagai berikut:

Harga keseluruhan kamar perhari dalam satu orang = Harga keseluruhan dari rawat inap selama setahun di bagi dengan Jumlah hari rawat inap selama setahun $=$ Rp. 323.434.000 : $2565=$ Rp. 126.242,78. Dengan mengunakan perhitungan berdasarkan variable costing dengan memperhitungkan biaya rata-rata yang sudah di tetapkan maka hasil yang didapat 
sebesar Rp. 126.242 jika dibandingkan dengan tariff yang sudah ditetapkan rumah sakit saat ini sebesar Rp. 100.000. Hasil analisis yang di peroleh maka tarif yang ditetapkan rumah sakit terlalu rendah jika di bandingkan dengan hasil yang diperoleh berdasarkan variable costing.

\section{Perbandingan Tarif Rumah Sakit dan Tarif berdasarkan Variable Costing.}

Tabel 6. Perbandingan tarif rumah sakit dan tarif berdasarkan variable costing

\begin{tabular}{llrr}
\hline No & Kamar & Tarif Rumah Sakit & Tarif Berdasarkan Variable Costing \\
\hline 1 & Kamar VIP & Rp. 375.000 & Rp. 385.000 \\
2. & Kamar I & Rp. 225.000 & Rp. 246.000 \\
3. & Kamar II & Rp. 150.000 & Rp. 192.152 \\
4. & Kamar IV & Rp. 100.000 & Rp. 126.242 \\
\hline Sumber: Rumah Sakit
\end{tabular}

Sumber: Rumah Sakit GMIM Siloam Sonder

\section{KESIMPULAN DAN SARAN}

\subsection{Kesimpulan}

Berdasarkan hasil penelitian dan pembahasan yang sudah ada pada bab sebelumnya maka peneliyi dapat menarik keimpulan sebagai berikut :

1. Berdasarkan hasil penelitian yang didaptkan berdarkan perhitungan mengunalan variable costing dengan menghitung biaya rata-rata yang sudah ditetapkan dan juga melakukan pengelompokan biaya-biaya maka dapat di ketahui biaya rata-rata perpasien pada Rumah Sakit GMIM Siloam Sonder adalah sebegai berikut: (a) Kamar VIP adalah sebesar Rp 385,667; (b) Kamar kelas I adalah sebesar Rp. 246,391; (c) Kamar kelas II adalah sebesar Rp 192,152; dan (d) Kamar kelas III adalah sebesar Rp 126,243.

2. Dari hasil yang didapat oleh penulis dengan mengunakan metode variable costing dengan tariff yang sudah di tetapkan rumah sakit saat ini terdapat perbedaan yang signifikan jauh diaman tariff yang sudah ditetapkan oleh rumah sakit terlalu rendah setelah dibandingakan dengan hasil yang di dapat oleh penulis.

\subsection{Saran}

Saran dari penulis berhubungan dengan analisis penntuan tarif rawat inap berdasarkan variable costing di Rumah Sakit GMIM Siloam Sonder Kabupaten Minahasa sebagai berikut:

1. Tarif yang di tetapkan rumah sakit dengan tarif yang sudah didaptkan peneliti memiliki perbedaan dimana tarif yang di tetapka rumah sakit terlalu rendah, maka perlu dilakukan evaluasi kembali karena sudah kurang relevan dengan keadaan sekarang, karena tarif tentunya akan berpengaruh dalam keuntungan bisnis rumah sakit.

2. Untuk penelitian akan dilakukan selanjutnya harus di tambahkan objek penelitian sehingga bisa dibandingkan dengan objek-objek tersebut.

3. Baiknya pihak Rumah sakit mengkaji kembali tariff yang sudah ada karena di bandingkan dengan tarif yang di dapat penulis tarif yang di gunakn rumah sakit sekarang sudah kurang relevan dengan keadaan sekarang terlalu rendah.

\section{DAFTAR PUSTAKA}

Antameng, D. P. Lambey, L. Gamaliel H. 2017. Penerapan Cost-Volume-Profit Dalam Pengambilan Keputusan Untuk Perencanaan Laba Pada Hotel Fajar Roon Manokwari. Jurnal Riset Akuntansi Going Concern 12(1), 2017, 91-97. Universitas Sam Ratulangi Manado. https://ejournal.unsrat.ac.id/index.php/gc/article/view/17141 
Darise T., Saerang D. P., dan Wangkar A. 2016. Analisis Penerapan Variabel Costing Sebagai Alat Untuk Menghitung Harga Pokok Produksi Pada Aksan Bakery Di Manado. Jurnal going concern vol.11 no 3. Universita Samratulangi Manado". https://ejournal.unsrat.ac.id/index.php/gc/article/view/13091

Kabib N., Nurrokhmini A., dan Hastutik T. 2017. Metode Variable Costing Sebagai Dasar Penentuan Harga Jual Produk. Prosiding The 5th University Research Colloquium. . Jurnal Akuntansi. Universitas Ahmad Dahlan. Yogyakarta

Mulyadi 2010 Akuntansi Biaya. Yogyakarta. Unit Penerbit Dan Percetakanskolah Tinggi Ilmu Manajemen YKPM” Prawironegoro. 2009. Akuntansi Manajemen. Jakarta Mitra Wacana Media.

Mulyadi. 2012. Akuntansi Biaya. Penerbit : UPP STIM YKPN. Yogyakarta

Mulyadi. 2014. Sistem Akuntnasi.Cetakan Keempat. Jakarta; Salemba Empat.

Mursyidi, 2008. Akuntansi Biaya. Penerbit: Refika Aditama, Bandung.

Prawironegoro. 2009. Akuntansi Manajemen. Jakarta Mitra Wacana Media

Suryabrata. 2013. Metodologi Penelitian. Penerbit : PT. Raja Grafindo Persada Jakarta

Simamora, H. 2012. Manajemen Sumber Daya Manusia. Yogyakarta."

Skousen, S. 2010. Intermetiade Accounting. Penerbit : Cincinnati, South Western

Wensen, C. R. Manossoh, H. Pinatik, S. 2016. Penerapan Metode Process Costing System Dalam Penentuan Harga Pokok Produksi Pada Pt. Conbloc Indonesia Surya. Jurnal Going Concern vol.11 no.3. Universitas Sam Ratulangi. Manado.” 